\title{
Removal of Sodium from Seawater Medium Using Photosynthetic Bacteria
}

\author{
Kei Sasaki, Yuichiro Hosokawa, Kenji Takeno, Ken Sasaki* \\ Department of Agricultural Bio-Recycle, Faculty of Engineering, Hiroshima Kokusai Gakuin University, Hiroshima, Japan \\ Email: *sasaken25@hi3.enjoy.ne.jp
}

How to cite this paper: Sasaki, K., Hosokawa, Y., Takeno, K. and Sasaki, K. (2017) Removal of Sodium from Seawater Medium Using Photosynthetic Bacteria. Journal of Agricultural Chemistry and Environment, 6, 133-143.

https://doi.org/10.4236/jacen.2017.63008

Received: July 15, 2017

Accepted: August 14, 2017

Published: August 17, 2017

Copyright () 2017 by authors and Scientific Research Publishing Inc. This work is licensed under the Creative Commons Attribution International License (CC BY 4.0).

http://creativecommons.org/licenses/by/4.0/

\begin{abstract}
The removal of sodium $(\mathrm{Na})$ from seawater using two photosynthetic bacteria was investigated using Rhodobacter sphaeroides SSI (SSI) and Rhodovulum sp. which is a marine photosynthetic bacterium. Both Rhodovulum sp. and acclimated SSI were shown to grow well in a $3 \% \mathrm{NaCl}$ supplemented glutamate-malate medium. The maximum rate of $\mathrm{Na}$ removal was $39.3 \%$ by SSI and $64.9 \%$ by Rhodovulum sp. after two days cultivation under static light conditions. However, $\mathrm{Na}$ was re-released back into the medium after two to three days. When a nutrient-supplemented seawater medium $(3.3 \% \mathrm{NaCl}$, $13.10 \mathrm{gNa} / \mathrm{l})$ was used, the maximum $\mathrm{Na}$ removal rates were $30.3 \%(9.05$ $\mathrm{gNa} / \mathrm{l})$ by SSI and $48.9 \%$ (6.69 $\mathrm{gNa} / \mathrm{l})$ by Rhodovulum sp., under static light conditions. Similar growth and Na removal rates were found under aerobic dark cultivation. In this case, no re-release of $\mathrm{Na}$ was observed with either bacterium. Two stages culturing was conducted first, with Rhodovulum sp. and then with SSI replacement. The $\mathrm{Na}$ concentration was reduced to 0.79 $\mathrm{gNa} / 1$ (94.0\% removal) after cultivation for eight days under aerobic dark conditions. The supernatant was applied successfully as a liquid fertilizer in the cultivation of Japanese radish.
\end{abstract}

\section{Keywords}

Removal of Sodium, Marine Photosynthetic Bacteria, Desalinization, Replacement Culture, Liquid Fertilizer

\section{Introduction}

Photosynthetic bacteria that produce extracellular polymeric substances (EPS) on the cell surface adsorb cationic metals such as $\mathrm{Cd}, \mathrm{Pb}, \mathrm{Cr}, \mathrm{Hg}, \mathrm{Cu}$ and $\mathrm{As}$ at rates between $85 \%$ and $100 \%$ using the negative charge of the EPS [1] [2]. By the same process, Rhodobacter sphaeroides SSI (SSI) able to remove radionuclides at 
rates of $95 \%$ for U, $82 \%$ for Sr and $58 \%$ for Co [2]. SSI has also been observed to adsorb Cs from waste water at rates approaching about $100 \%$ [3], but this seems to be closely related to the potassium transport system of photosynthetic bacteria [4]. In contrast, the marine photosynthetic bacterium, Rhodovulum sp. Accumulate abundant EPS on its cell surface allowing it to perform relatively strong self-immobilization [5].

The Great East Japan Earthquake occurred in March 2011. It released large amounts of radioactive materials, mainly Cs, from the Daiichi Nuclear Power Plant in Fukushima which then began to spread throughout the local and regional environment. In a previous study, we investigated the removal of radioactive Cs from the water and sediment mud of a swimming pool Fukushima City, demonstrating removal rates of almost $100 \%$ and $93 \%$ from the water and sediment mud of a swimming pool, respectively. This was achieved in four days using aerobic treatment with SSI immobilized alginate beads [6]. Removal of radioactive Cs from agricultural soil in Minami-Souma City and Namie Town, Fukushima was demonstrated using the same processes. In this case, the removal rate was between $60 \%$ and $75 \%$ [7]. Vegetables cultivated using the remediated soil were shown to have radioactivity of less than $100 \mathrm{~Bq} / \mathrm{kg}$ which is within the recommended limit for human consumption in Japan [8]. These studies demonstrated the ability of the SSI strain to remove heavy metals, toxic metals and other cationic metals.

Panwichian et al. reported removal rates using newly isolated photosynthetic bacteria of the NW16 and the KMS 24 strains of $39 \%$ for $\mathrm{Pb}, 20 \%$ for $\mathrm{Cu}, 7 \%$ for $\mathrm{Cd}, 5 \%$ for $\mathrm{Zn}$, and $31 \%$ for $\mathrm{Na}$. These stains were cultured in a $3 \% \mathrm{NaCl}$ seawater medium and exhibited $\mathrm{Na}$ reduction under microaerobic light (static light) and aerobic dark conditions. However, the precise function of $\mathrm{Na}$ reduction wasunclear [9]. Amezago et al. reported low-cost bio-desalinization of seawater using photosynthetic bacteria [10].

This study focused on the $\mathrm{Na}$ removal using two photosynthetic bacterial strains using a synthetic medium and a nutrient supplemented seawater medium (NSSW medium). Practical Na removal was demonstrated using both strains.

\section{Materials and Methods}

\subsection{Photosynthetic Bacteria and Media}

The marine photosynthetic bacterium used was Rhodovulum sp. [5] and a fresh water photosynthetic bacterium, Rhodobacter sphaeroides SSI [2] [3] was also used, both of which produce EPS on the cell surface. Rhodovulum sp. requires a medium in which the $\mathrm{NaCl}$ concentration is greater than $0.5 \%$, whereas SSI will not normally grow when the $\mathrm{NaCl}$ concentration exceeds $0.5 \%$. Rhodovulum sp. was isolated from the sea sediment mud of a shrimp cultivation pond in Thailand [5]. SSI strain was obtained as a spontaneous mutant which has self-flocculation ability from Rhodobacter sphaeroides S [2]. R. sphaeroides $\mathrm{S}$ has practically applications in wastewater treatment and has been used more than 40 years 
in Japan [11].

Two $\mathrm{NaCl}$ supplemented glutamate-malate media ( $3 \% \mathrm{NaCl}$ and $1 \% \mathrm{NaCl}$ ) were used for growth and Na removal. The composition of both GM media was as follows (g/l): sodium-L glutamate 3.8, DL-Malic acid 2.7, $\left(\mathrm{NH}_{4}\right)_{2} \mathrm{HPO}_{4} 0.8$, Yeast extract 1.0, $\mathrm{KH}_{2} \mathrm{PO}_{4} 0.5, \mathrm{~K}_{2} \mathrm{HPO}_{4} 0.5, \mathrm{MgSO}_{4} \cdot 6 \mathrm{H}_{2} \mathrm{O} 0.2, \mathrm{CaCl}_{2} \cdot 2 \mathrm{H}_{2} \mathrm{O} 0.05$, Thiamine-HCl $1 \times 10^{-3}$, Nicotinic acid $1 \times 10^{-3}$, Biotin $0.01 \times 10^{-3}$. This GM medium was modified from GM supplemented medium by Lascelles [12]. $\mathrm{NaCl}$ was then added to bring the concentrations to $3 \%$ and $1 \%$.

An NSSW medium with $3.3 \% \mathrm{NaCl}$, was prepared by nutrients the addition of $5.0 \mathrm{~g} / \mathrm{l}$ of glucose and $2.0 \mathrm{~g} / \mathrm{l}$ of peptone. Seawater was taken from Hiroshima Bay, Japan. The initial $\mathrm{pH}$ of the medium was adjusted to $7.0 \pm 0.1$ using a $\mathrm{HH}_{4} \mathrm{OH}$ solution or $6 \mathrm{~N}-\mathrm{HCl}$. Media were sterilized by autoclave (at $121^{\circ} \mathrm{C}, 20$ $\min$. ).

To improve the growth of SSI in the $3 \% \mathrm{NaCl}$ GM medium, acclimation was performed. First, the SSI was cultured in a $0.5 \% \mathrm{NaCl}$ GM medium under static light conditions for two to three weeks. Slow growth was observed. The culture broth was then transferred to a $1 \% \mathrm{NaCl} \mathrm{GM}$ medium. Again, slow growth was observed. Cultivation was then performed three to five times in a $2 \% \mathrm{NaCl} \mathrm{GM}$ medium, and three to five times in $3 \% \mathrm{NaCl} \mathrm{GM}$ medium. The acclimated strain of SSI was then placed on agar plate of $3 \% \mathrm{NaCl} \mathrm{GM}$ medium. Cultivation of all strains was conducted at $30 \pm 0.5^{\circ} \mathrm{C}$.

\subsection{Cultivation}

Pre-culturing was performed in a $300 \mathrm{ml}$ conical flask ( $100 \mathrm{ml}$ medium) under micro-aerobic condition with static light for three days. Illumination was supplied by a tungsten bubble at $5 \mathrm{klux}\left(80 \mu \mathrm{E} / \mathrm{m}^{2} \cdot \mathrm{sec}\right)$ onto the surface of the flask. For the main culture, a $300 \mathrm{ml}$ conical flask ( $200 \mathrm{ml}$ medium) was held under the same conditions for five days. An aerobic dark culture was prepared in a $300 \mathrm{ml}$ conical flask (medium $150 \mathrm{ml}$ ) placed on rotary shaker $(120 \mathrm{rpm}$ ) for five days. Inoculation of the pre-cultured broth was conducted at $10 \%(\mathrm{v} / \mathrm{v})$.

Culture replacement was performed in two stages. For Rhodovulum sp., culturing was first performed using the NSSW medium under both static light and aerobic dark conditions. After four days, the broth was centrifuged at 10,000 xg for $20 \mathrm{~min}$ to isolate the supernatant. Centrifugation was performed at room temperature $\left(23^{\circ} \mathrm{C}-30^{\circ} \mathrm{C}\right)$. This was sterilized using Millipore filter $(0.45 \mu \mathrm{m}$ pore size) and placed in a sterilized flask. In the second stage, SSI pre-cultured broth was inoculated at $10 \%(\mathrm{v} / \mathrm{v})$ and cultivated for further four days under static light or aerobic dark conditions. On day eight, centrifugation at 10,000xg $20 \mathrm{~min}$. was performed at room temperature $\left(23^{\circ} \mathrm{C}-30^{\circ} \mathrm{C}\right)$. In the next stage the experiment, the supernatant obtained was used as liquid fertilizer. Static light and aerobic dark culture were performed with $200 \mathrm{ml}$ and $150 \mathrm{ml}$ culture broth, respectively, in $300 \mathrm{ml}$ flask. Cultivation temperature of Rhodovulum sp. and SSI was $30 \pm 0.5^{\circ} \mathrm{C}$. 
During the cultivation of both strains, $10 \mathrm{ml}$ of culture broth was pulled out and measured $\mathrm{OD}_{660}$ for the growth evaluation every day. And then, culture broth was centrifuged $\left(10,000 \mathrm{xg}, 20 \mathrm{~min}\right.$.) at $4^{\circ} \mathrm{C}$. From the supernatant, $\mathrm{Na}$ concentration was measured.

\subsection{Cultivation of Japanese Radish}

Sprout of Japanese radish (Raphanas sativas) were cultured in the polyethylene container $(10 \times 20 \times 5 \mathrm{~cm})$ on $2 \mathrm{~cm}$ layer of cotton(put on the bottom) with a supply of deionized water to have wet condition. The container was placed near a window under indirect sunlight at roomtemperature $\left(23^{\circ} \mathrm{C}-30^{\circ} \mathrm{C}\right)$.

As a control, sprouts were sprayed with a commercial liquid fertilizer, diluted 1000 times HYPONeX stock solution (HYPONeX Japan Co. Ltd.) at one to three days intervals. A second container, supernatant as liquid fertilizer was sprayed in the same manner as the control. Growth and damages were observed for about one month.

\subsection{Analysis}

The growth of the photosynthetic bacteria was observed at $\mathrm{OD}_{660}$ using a spectrophotometer (Shimadzu, UV-1700). The Na concentration was measured using anatomic adsorption spectrophotometer (Shimadzu, AA-6200). Experimental errors of $\mathrm{OD}_{660}$ and $\mathrm{Na}$ were the mean value $\pm 5 \%$ and $\pm 10 \%$, respectively. Data were the mean values from triplet experiments.

\section{Results and Discussion}

\subsection{Na Removal from $3 \%$ NaClGM Medium}

Figure 1(a) and Figure 1(b) show the growth and Na removal of photosynthetic bacteria for $3 \% \mathrm{NaCl} \mathrm{GM}$ medium (11.80 gNa/l), respectively. The SSI grew well even at this high salinity, and Na removal of $1.80 \mathrm{~g} / \mathrm{l}$ (39.3\% removal) was observed after three days culture under static light conditions (Figure 1(a)). Almost the same growth and $\mathrm{Na}$ removal pattern were observed under the aerobic dark conditions (Figure 1(b)). These results reflected the acclimation of the SSI, which is known as a fresh water photosynthetic bacterium and cannot normally grow when the $\mathrm{NaCl}$ concentration exceeds $0.5 \%$.

In contrast, Rhodovulum sp. showed more rapid growth and greater Nareduction. The maximum $\mathrm{Na}$ removal rate of $4.25 \mathrm{gNa} / 1$ (64.9\% removal) was recorded after one day under the static light conditions (Figure 1(c)), However, once growth was became steady, the $\mathrm{Na}$ concentration began to increased again, finally returning to almost the original level. A very similar pattern was observed under the aerobic dark conditions, although the rate of growth was slower.

It is well known that the energy status of the cells of photosynthetic bacteria affects the uptake of $\mathrm{Na}$. Under high energy conditions, $\mathrm{Na}$ is incorporated, whereas, under low energy conditions $\mathrm{Na}$ is exported [10] [13]. In the final stage 


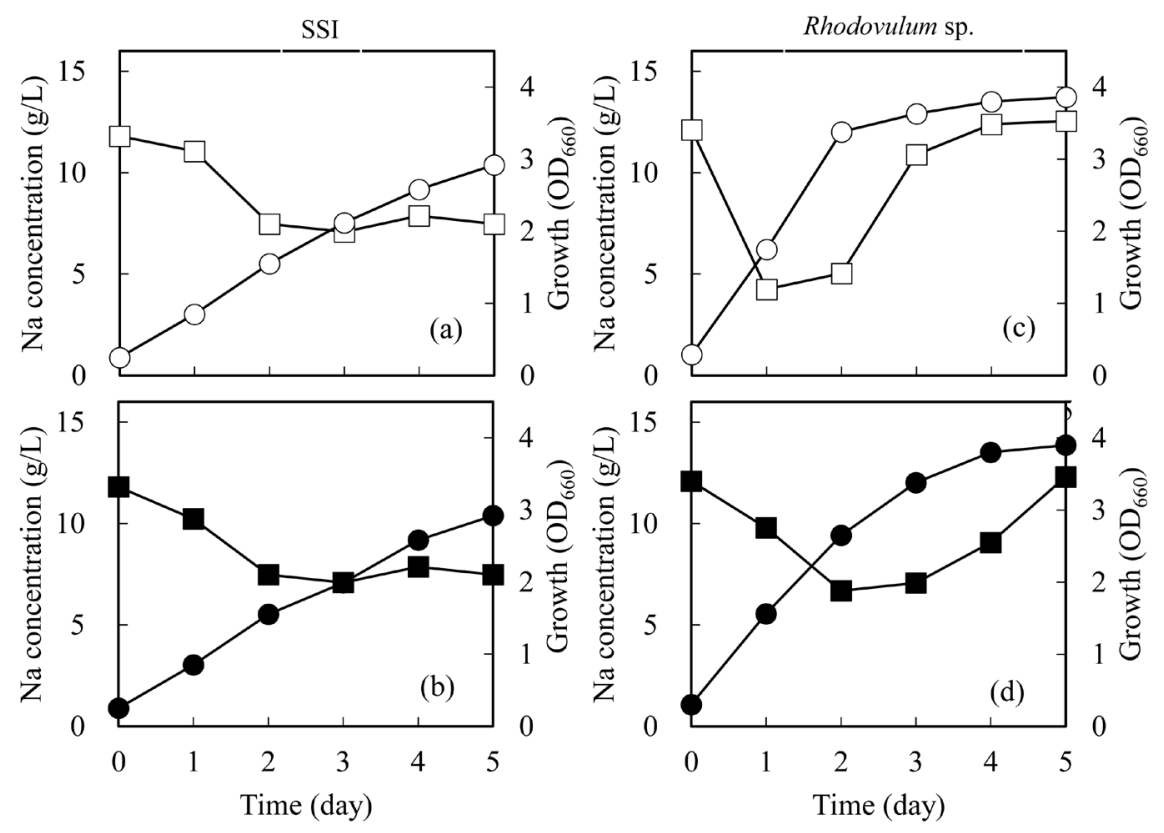

Figure 1. Growth and Na removal by Rhodobacter sphaeroides SSI and Rhodovulum sp. with $3 \% \mathrm{NaCl}$ supplemented glutamate-malate medium. $\bigcirc$ : growth under static light conditions; $\square$ : Na removal under static light conditions; 0 : growth under aerobic dark conditions; $\mathbf{\square}$ : Na removal under aerobic dark conditions.

of growth, energy harvesting fell because of the limitations on carbon, light and oxygen, so that $\mathrm{Na}$ might be exported again into the medium.

\subsection{Na Removal from $1 \%$ NaCl Supplemented GM Medium}

As shown in Figure 2(a), the SSI grew well in the 1\% $\mathrm{NaCl}$ GM medium (3.93 $\mathrm{gNa} / \mathrm{l}$ ), and the $\mathrm{Na}$ concentration fell almost zero (about $100 \%$ removal) after one day under the static light conditions. However, after three days, Nabegan is to be exported into the medium. We observed almost the same growth and $\mathrm{Na}$ removal pattern under the aerobic dark conditions (Figure 2(b)).

The growth of Rhodovulum sp in the $1 \% \mathrm{NaCl}$ GM medium (Figure 2(c)) was slower than that in the $3 \% \mathrm{NaCl} \mathrm{GM}$ medium (Figure $1(\mathrm{c})$ ). Na concentration again fell to almost zero after one day both the static light and aerobic dark conditions.

In the removal of Na by SSI, the negative charge of the EPS on the cell surface appear to function in the same way the adsorption of cationic heavy metals and radionuclide [1] [2]. However, the process by Rhodovulum sp. removes $\mathrm{Na}$ by its $\mathrm{Na}$ transport system of cells compared with the adsorption by EPS of negative charge [10] [13]. The functions of Na removal by Rhodovulm sp. needs further investigation.

\subsection{Na Removal in the Seawater Medium}

The SSI strain successfully grew in the NSSW medium removing up to $30.3 \%$ of the $\mathrm{Na}$ after four days under both the static light conditions (Figure 3(a)) and 


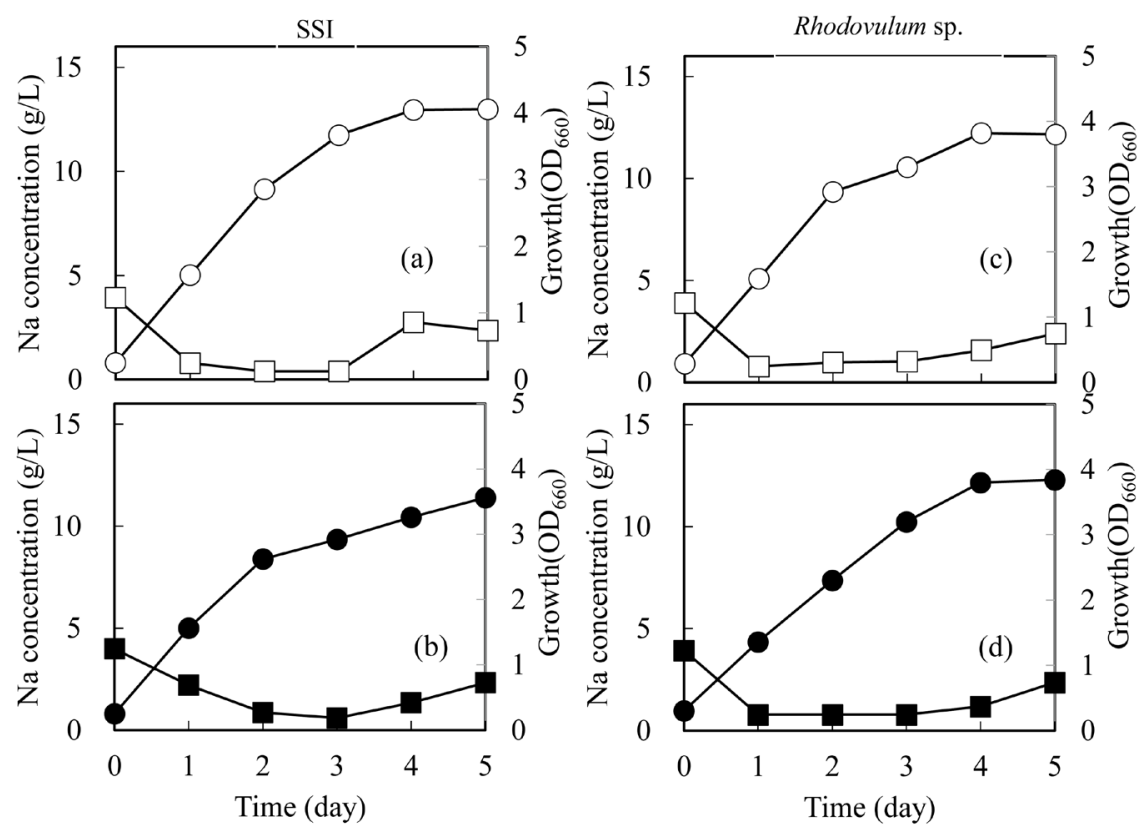

Figure 2. Growth and Na removal by Rhodobacter sphaeroides SSI and Rhodovulum sp. with $1 \% \mathrm{NaCl}$ supplemented glutamate-malate medium. Symbols are the same as in Figure 1.
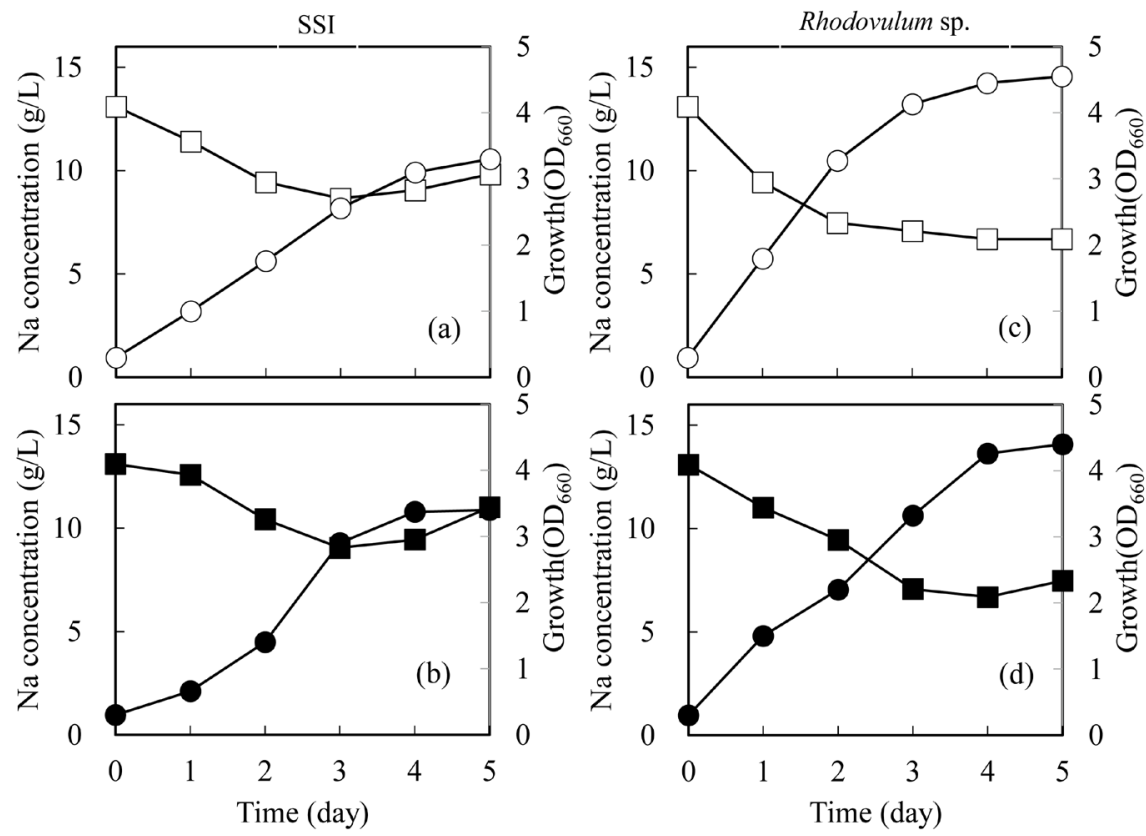

Figure 3. Growth and Na removal by Rhodobacter sphaeroides SSI and Rhodovulum sp. with a NSSW medium. Symbols are the same as in Figure 1.

the aerobic dark conditions (Figure 3(b)). This was almost the same as the results from the $3 \% \mathrm{NaCl} \mathrm{GM}$ medium (Figure 1 (a)).

When Rhodovulum sp. was grown in the NSSW medium under the static light (Figure 3(c)) and aerobic dark conditions (Figure 3(d)), Na removal reached $48.9 \%$ after four days and did not subsequently reduce and no export of $\mathrm{Na}$. The 
addition of nutrients (containing peptone, high molecular weight organic materials) may have extended energy supply and suppressed $\mathrm{Na}$ export.

Both SSI and Rhodovulum sp. were able to remove Na from the NSSW medium under the aerobic dark conditions. This suggests that the use of photosynthetic bacteria offers a convenient, low-cost approach for the desalinization of seawater. In other desalinization processes that use photosynthetic bacteria, for example, cyanobacteria, large ponds are required to provide sunlight for growth of cells [10].

\subsection{Two Stages Na Removal in the NSSW Medium by Culture Replacement}

We observed relatively high Na reduction by Rhodovulum sp. and SSI in the NSSW medium and almost nore-export of $\mathrm{Na}$ into the broth. Na removal was performed in two stages. As can be seen from Figure 4, in the first stage, Rhodovlum sp. was cultured in the NSSW medium at $13.1 \mathrm{gNa} / 1$. After four days, the $\mathrm{Na}$ concentration was reduced to $5.9 \mathrm{gNa} / \mathrm{l}$ (55.9\% reduction) under static light conditions and to $5.51 \mathrm{gNa} / 1$ (57.9\% reduction) under aerobic dark conditions. In the second stage, Rhodovulum sp. cells were separated using centrifugation, and the SSI culture was replaced using the supernatant after sterilization.

The minimum $\mathrm{Na}$ concentration of $0.79 \mathrm{gNa} / \mathrm{l}(0.2 \% \mathrm{NaCl}$ concentration) was reached after four days of the second stage (total culture time of eight days) under both conditions. This represented a $94.0 \%$ removal of $\mathrm{Na}$ from the seawater. It must be emphasized that it was high level desalinization establishment using the two stages aerobic culture. For example, Panwichian et al. reported that reduction to $31 \%$ of Na removal was observed using photosynthetic bacteriacul-

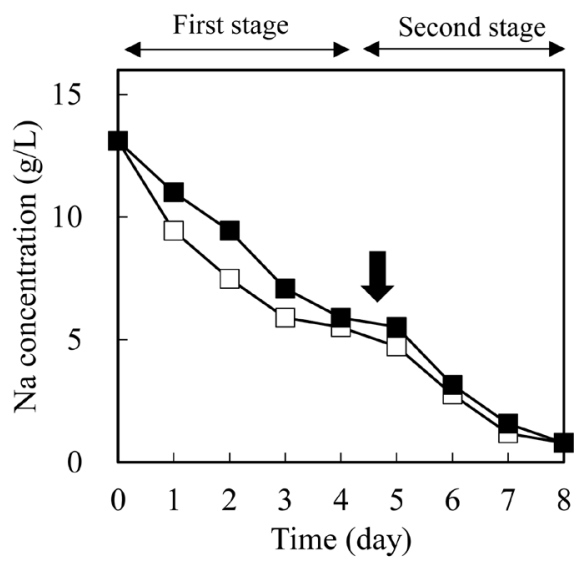

Figure 4. Na removal during Rhodovulum sp. culture with a NSSW medium in the first stage. Na removal during Rhodobacter sphaeroides SSI culture with nutrients supplemented supernatant of cultured broth in the second stage. Arrows indicate the Rhodovulum cells separation by centrifugation and supernatant obtained for replacement culture (see M aterials and Methods). $\square$ : Na removal under static light conditions; $\mathbf{\square}$ : Na removal under aerobic dark conditions. 
ture from the seawater [9]. The high level of $\mathrm{Na}$ removal from seawater found in our study has not been previously reported when using photosynthetic bacteria, including cyan bacteria.

\subsection{Use of Culture Supernatant for Vegetable Culture}

The supernatant obtained by centrifugation was used as a liquid fertilizer for the cultivation of Japanese radish. The growth and the appearance of sprouts were similar to the samples grown using the conventional liquid fertilizer of HYPONeX solution for one month (data not shown).

The supernatant contained photosynthetic bacterial metabolites such as amino acids, organic acids and extracellular products. These might support vegetable growth at a low $\mathrm{Na}$ concentration. For example, a photosynthetic bacterial supernatant usually contains 10 - $30 \mu$ mole/I of 5-aminolevulinic acid (ALA). This extracellular product supports the growth of rice seedling [14]. ALA has already been commercialized and is used as a liquid fertilizer in the cultivation of crops, vegetables and flowers [15].

This study suggests the possibility of producing liquid fertilizer from seawater after two stage treatment using photosynthetic bacteria. This would support agriculture in regions where fresh water is scarce, such as islands and coastal areas of Japan. However, further investigation and long term observation of this liquid fertilizer (to assess its safety) will be needed before applying it to the cultivation of vegetables, plants or flowers.

\subsection{Proposals for Practical NaCl Removal from Seawater and Production of Liquid Fertilizer}

Based on our results, we propose the practical process of $\mathrm{Na}$ reduction and bioconversion of seawater into liquid fertilizer as shown in Figure 5. After nutrients are added and the seawater issterilized with addition of $\mathrm{Cl}_{2}$, aeration beginning. The Rhodovulum sp. seed culture broth is inoculated after the $\mathrm{Cl}_{2}$ level fell below $0.1 \mathrm{mg} / \mathrm{l}$. A dense inoculation of about $10 \%(\mathrm{v} / \mathrm{v})$ is used to maintain the dominance of the Rhodovulum sp. A seed culture broth is obtained from the NSSW medium in a Jar ferment or culture. After sterilization in an autoclave, pure culture broth is obtained, to preserve the dominance of photosynthetic bacteria, anaerobic digestion liquor from food wastes, agricultural wastes or night soil are preferred as nutrients. Lower fatty acids such as acetic, propionic and butyric acids are suitable carbon source for photosynthetic bacteria but not preferable for other bacteria [11] [15].

Photosynthetic bacteria can grow without large contamination under low oxygen level with a dissolved oxygen level below $1.0 \mathrm{mg} / \mathrm{l}$. In Japan, practical wastewater treatment plants handling food processing wastewater mainly use activated sludge treatment. Photosynthetic bacteria are usually dominant under the low oxygen level in this aerobic treatment [11] [15]. But, fresh photosynthetic bacterial seed cultures must sometimes be added to maintain this dominance. This is not practically challenging in practical applications [11] [16] [17]. 


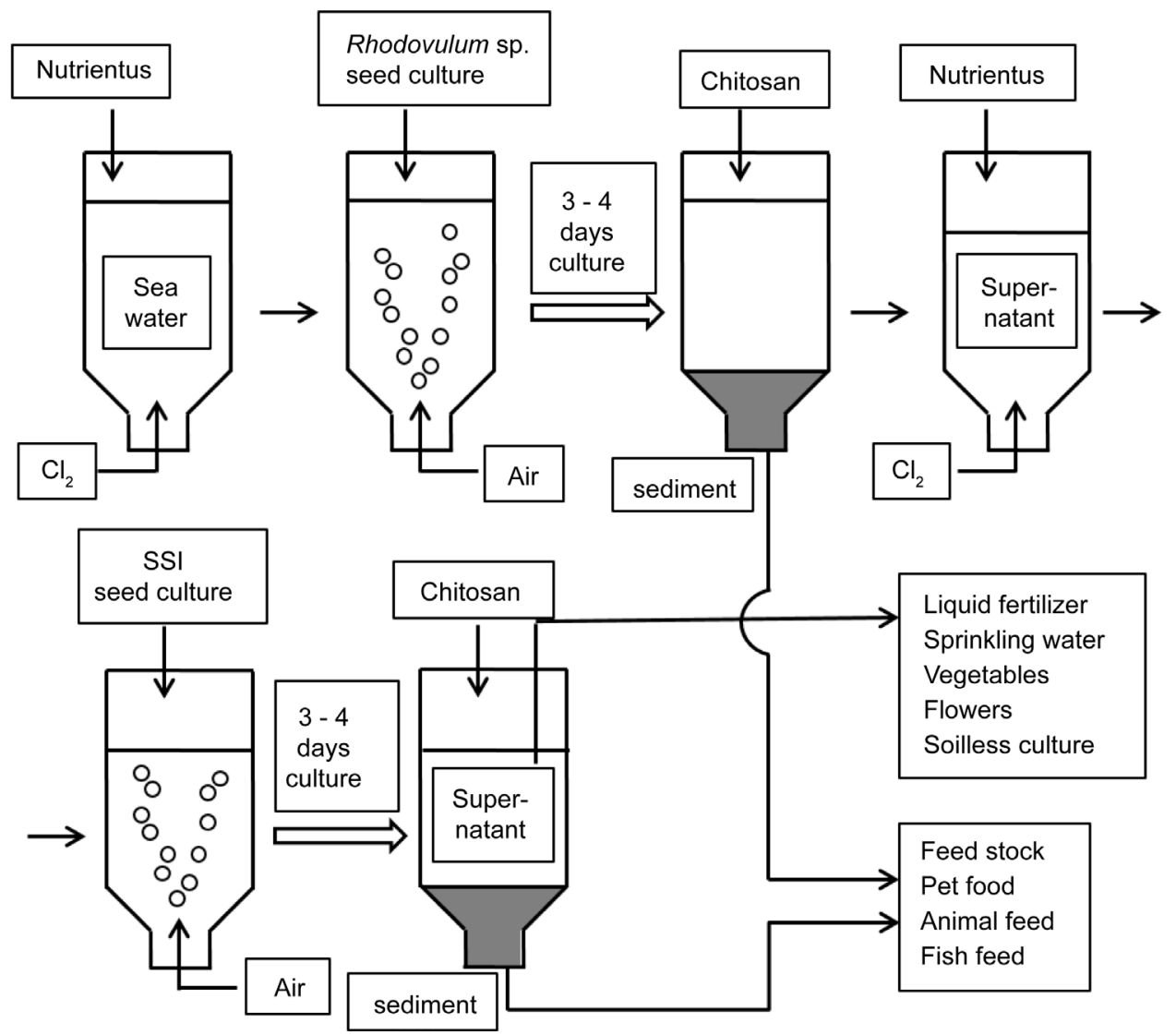

Figure 5. Schematic of the practical process of seawater bioconversion into liquid fertilizer or sprinkling water using photosynthetic bacteria. Steps: 1) Add nutrients and $\mathrm{Cl}_{2}$;2) Aeration and Rhodovulum sp. seed culture inoculum $\left.\left(<0.1 \mathrm{mgCl}_{2} / \mathrm{l}\right) ; 3\right)$ Three to four days culture; 4$)$ Add chitosan and cells sediment recovery; 5) Add nutrients and $\left.\mathrm{Cl}_{2} ; 6\right)$ Aeration and SSI seed culture inoculation $(<0.1$ $\left.\mathrm{mgCl}_{2} / \mathrm{l}\right)$; 7) Three to four days culture; 8) Add chitosan and cells sediment recovery. Supernatant of SSI replacement culture is used as a liquid fertilizer or sprinkling water. Nutrients are the wastes from food processing or agriculture.

After cultivation of Rhodovulum sp., chitosan sedimentation is performed to separate the cells. Chitosan is a good coagulant and for photosynthetic bacteria and can easily sediment the bacteria. As chitosan is a natural material, the sedimented cells can also be used as a feedstock for production of pet food, animal feed and fish feed. After three to four days of SSI culture, the cells are again sedimented and separate using chitosan treatment. The supernatant obtained can be used as a liquid fertilizer or sprinkling water for vegetables, flowers and water source for soilless culture or hydroponic culture.

In this study, we demonstrated possibility of the bioconversion of seawater into liquid fertilized by removal of Na using two strains of photosynthetic bacteria. The comparative cost of this alternative approach is currently being investigated.

\section{Conclusions}

The removal of $\mathrm{Na}$ by photosynthetic bacteria was investigated, and the follow- 
ing results were obtained.

1) Acclimated SSI was shown to grow well in a $3 \% \mathrm{NaClGM}$ medium (11.8 $\mathrm{gNa} / \mathrm{l})$. The maximum $\mathrm{Na}$ removal was $39.3 \%(7.16 \mathrm{gNa} / \mathrm{l})$ under static light conditions and $36.7 \%(7.47 \mathrm{gNa} / \mathrm{l})$ under aerobic dark conditions.

2) Rhodovulum sp. also grew well in the $3 \% \mathrm{NaCl} \mathrm{GM}$ medium maximum $\mathrm{Na}$ removal of $64.9 \%(4.2 \mathrm{gNa} / \mathrm{l})$ was observed after one day of culture under both conditions but $\mathrm{Na}$ began to be released back into the broth after two days.

3) In the NSSW medium $(3.3 \% \mathrm{NaCl}, 13.1 \mathrm{gNa} / \mathrm{l})$, SSI was shown to remove up to $30.3 \%$ of the $\mathrm{Na}(9.05 \mathrm{gNa} / \mathrm{l})$ after four days under the static light conditions, and Rhodovulum sp. up to $48.9 \%$ (6.69 gNa/l). In this case, almost no $\mathrm{Na}$ was later exported. Similar results were observed under the aerobic dark conditions.

4) Tow stage culturing first, with Rhodovulum sp. then with an SSI replacement culture was performed under the aerobic dark conditions using the NSSW medium. Finally, the Na concentration was reduced to $0.79 \mathrm{gNa} / 1$ ( $94 \%$ removal) after eight days. This represented a high level of desalinization.

5) The supernatant $(0.2 \% \mathrm{NaCl})$ was used in the cultivation of Japanese radish, demonstrating its use as a liquid fertilizer.

6) Our study demonstrated a practical approach to the bioconversion of seawater into liquid fertilizer using Rhodovulum sp. and SSI.

\section{References}

[1] Watanabe, M., Kawahara, K., Sasaki, K. and Noparatnaraporn, N. (2003) Biosorption of Cadmium Ions Using Photosynthetic Bacterium, Rhodobactersphaeroides $\mathrm{S}$ and a Marine Photosynthetic Bacterium, Rhodovulum sp. and Their Biosorption Kinetics. Journal of Bioscience and Bioengineering, 95, 374-378. https://doi.org/10.1016/S1389-1723(03)80070-1

[2] Sasaki, K., Hara, C., Takeno, T., Okuhata, H. and Miyasaka, H. (2012) Metals Related to Radionuclides and Heavy Metals Removal Using Photosynthetic Bacteria Immobilized Recovery Type Porous Ceramic. Japanese Journal of Water Treatment Biology, 46, 119-127.

[3] Sasaki, K., Morikawa, H., Kishibe, T., Takeno, K., Mikami, A., Harada, T. and Ohta, M. (2012) Simultaneous Removal of Cesium and Strontium Using a Photosynthetic Bacterium, Rhodobacter sphaeroides SSI Immobilized on Porous Ceramic Made from Waste Glass. Advances in Bioscience and Biotechnology, 4, 6-13. https://doi.org/10.4236/abb.2013.41002

[4] Sasaki, K. and Takeno, K. (2014) Practical Decontamination of Radioactive Polluted Soil by Photosynthetic Bacteria and Recycle Use for Agriculture. Seibutu-Kougaku Kaishi, 92, 146-156.

[5] Watanabe, M., Sasaki, K., Nakashimada, T., Noparatnaraporn N. and Nishio, N. (1998) Growth and Flocculation of a Marine Photosynthetic Bacterium Rhodovulum sp. Applied Microbiology and Biotechnology, 50, 682-691. https://doi.org/10.1007/s002530051351

[6] Sasaki, K., Morikawa, H., Kishibe, T., Mikami, A., Harada, T. and Ohta, M (2012) Practical Removal of Radioactivity from Sediment Mud in a Swimming Pool in Fukushima, Japan by Immobilized Photosynthetic Bacteria. Bioscience, Biotechnology, 
and Biochemistry, 76, 859-862. https://doi.org/10.1271/bbb.110853

[7] Sasaki, K., Morikawa, H., Kishibe, T., Takeno, K., Mikami, A., Harada, T. and Ohta, M. (2012) Practical Removal of Radioactivity from Soil in Fukushima Using Immobilized Photosynthetic Bacteria Combined with Anaerobic Digestion and Lactic Acid Fermentation as Pre-Treatment. Bioscience, Biotechnology and Biochemistry, 76, 1809-1814. https://doi.org/10.1271/bbb.120440

[8] Sasaki, K., Nakamura, K., Takeno, K., Shinkawa, H., Das, N. and Sasaki, K. (2015) Removal of Radioactivity from Sediment Mud and Soil and Use for Cultivation of Safe Vegetables in Fukushima, and Removal of Toxic Metals Using Photosynthetic Bacteria. Journal of Agricultural Chemistry and Environment, 4, 63-75. https://doi.org/10.4236/jacen.2015.43007

[9] Panwichian, S., Kantachote, D., Wittayaweerasak, B. and Mallavarapu, M. (2010) Isolation of Purple Nonsulfur Bacteria for the Removal of Heavy Metals and Sodium from Contaminated Shrimp Ponds. Electron Journal of Biotechnology, 13, 112. https://doi.org/10.2225/vol13-issue4-fulltext-8

[10] Amezaga, J., Amtman, A., Biggs, C.A., Bond, T., Gandy, C.J., Honsbein, A., Karunakaran, E., Lawton, L., Madsen, M.A., Minas, K. and Templeton, R. (2014) Biodesalination: A Case Study for Applications of Photosynthetic Bacteria in Water Treatment. Plant Physiology, 164, 1661-1676.

https://doi.org/10.1104/pp.113.233973

[11] Kitamura, H., Kurosawa, K. and Kobayashi, M. (1984) Organic Wastewater Treatment by Photosynthetic Bacteria. In: Kitamura, H., Morita, S. and Yamashita, J., Eds., The Photosynthetic Bacteria, Gakkai Shyuppan Center, Tokyo, 112-121.

[12] Lascelles, J. (1956) The Synthesis of Porphyrins and Bacteriochlorophyll by Cell Suspensions of Rhodopseudomonas sphaeroides. Biochemical Journal, 62, 78-93. https://doi.org/10.1042/bj0620078

[13] Miller, A.G., Turpin, D.H. and Canvin, D.T. (1894) $\mathrm{Na}^{+}$Requirement for Growth, Photosynthesis, and pH Regulation in the Alkalitolerant Cyanobacterium Synechococcus leopoilensis. Journal of Bacteriology, 159, 100-106.

[14] Kantha, T., Kantachote, D. and Klongdee, N. (2015) Potential of Biofertilizers from Selected Rhodopseudomonas palustris Strains to Assist Rice (Oryza sativa L. Subsp. Indica) Growth under Salt Stress and Reduce Greenhouse Gas Emissions. Annals Microbiology, 65, 2109-2118. https://doi.org/10.1007/s13213-015-1049-6

[15] Sasaki, K., Sasaki, K. and Takeno, K. (2016) Application of Photosynthetic Bacteria for Agricultural, Environmental, Medical and Healthy Fields, and Future Prospect. Seibutu-Kougaku Kaishi, 94, 146-156.

[16] Madukasi, R.I., Dai, X. and Zhou, J. (2010) Potential of Phototrophic Bacteria in Treating Pharmaceutical Wastewater, International Journal of Environmental Science Technology, 7, 164-174. https://doi.org/10.1007/BF03326128

[17] Lu, H., Zhang, G., Dai, X. and He, C. (2010) Photosynthetic Bacteria Treatment of Synthetic Soybean Wastewater. Bioresouces Technology, 101, 7672-7674.

https://doi.org/10.1016/j.biortech.2010.04.074 
Submit or recommend next manuscript to SCIRP and we will provide best service for you:

Accepting pre-submission inquiries through Email, Facebook, LinkedIn, Twitter, etc. A wide selection of journals (inclusive of 9 subjects, more than 200 journals)

Providing 24-hour high-quality service

User-friendly online submission system

Fair and swift peer-review system

Efficient typesetting and proofreading procedure

Display of the result of downloads and visits, as well as the number of cited articles Maximum dissemination of your research work

Submit your manuscript at: http://papersubmission.scirp.org/

Or contact jacen@scirp.org 